\title{
Removal of chromium (VI) from aqueous solution using chemically modified orange (citrus cinensis) peel
}

\author{
Shadreck Mandina, Fidelis Chigondo, Munyaradzi Shumba, \\ Benias Chomunorwa Nyamunda, Edith Sebata \\ Lecturer, Department of Educational Foundations, Management and Curriculum Studies, Midlands State \\ University, Gweru, Zimbabwe \\ Lecturer, Department of Chemical Technology, Midlands State University, Gweru, Zimbabwe: \\ Lecturer, Department of Chemical Technology, Midlands State University, Gweru, Zimbabwe: \\ Lecturer, Department of Chemical Technology, Midlands State University, Gweru, Zimbabwe: \\ Lecturer, Department of Chemical Technology, Midlands State University, Gweru, Zimbabwe:
}

\begin{abstract}
The removal of $\mathrm{Cr}$ (VI) from aqueous solutions onto chemically modified orange peel was studied at varying initial metal concentrations, adsorbent doses, $p H$ and contact times. Batch experiments were carried out under optimized conditions to evaluate the adsorption capacity of the orange peel chemically modified with sodium hydroxide. The residual $\mathrm{Cr}$ (VI) concentrations after biosorption were analyzed by FAAS. The biosorbent was characterized by FT-IR spectroscopy and BET. The characterization of the orange peel biomass suggested the possible contribution of carboxyl and hydroxyl groups in $\mathrm{Cr}$ (VI) biosorption. Chemically modified orange peel exhibited more adsorption potential as compared to the raw orange peel. The biosorption efficiency of the orange peel was dependent on the $\mathrm{pH}$ of the $\mathrm{Cr}$ (VI) solution, with $\mathrm{pH} 2$ being optimal. The removal rate of $\mathrm{Cr}(V I)$ ions increased with increase in contact time and remained constant after an equilibrium time of $180 \mathrm{~min}$. The removal of Cr (VI) ions increased with increase in biosorbent concentration with the optimal adsorbent dosage at $4.0 \mathrm{mg} / \mathrm{L}$. The increase in initial $\mathrm{Cr}$ (VI) ion concentration led to an increase in the percentage removal of $\mathrm{Cr}(V I)$. The adsorption data fitted well with the Freundlich isotherm model with $R^{2}=$ 0.987 for the raw orange peel and $R^{2}=0.995$ for the modified orange peel. The Freundlich constants $K_{f}$ and $n$ were $97.07\left[\mathrm{mg} / \mathrm{g}(\mathrm{L} / \mathrm{mg})^{n}\right]$ and $0.79(\mathrm{~g} / \mathrm{L})$ for the raw orange peel and $139.0\left[(\mathrm{mg} / \mathrm{g})(\mathrm{L} / \mathrm{mg})^{n}\right]$ and $0.815(\mathrm{~g} / \mathrm{L})$ for modified orange peel respectively. The present study revealed that orange peel which is a low cost agricultural material could be used as an efficient sorbent for the removal of $\mathrm{Cr}(\mathrm{VI})$ from aqueous solutions and that chemical modification of the biosorbent using sodium hydroxide enhanced adsorption capacity.

Keywords: Adsorption isotherm, Biosorption, Chemical modification, Chromium (VI), Orange peel
\end{abstract}

\section{Introduction}

The removal of heavy metals from industrial effluents is a field of research that has attracted increasing attention from the scientific community as the quest for green chemistry takes centre stage. Heavy metals in wastewaters are hazardous to the environment and therefore their removal before waste water discharge is apparent [1]. These substances are stable and persistent environmental contaminants since they are nonbiodegradable [2]. Chromium is one of the toxic metals often found in effluents discharged from industries involved in paints, pigments, dyes, textiles, leather tanning, electroplating, metal finishing, nuclear power plants and chromate preparation [3]. Chromium can exist in several oxidation numbers but only chromium (III) and chromium (VI) are stable enough to occur in the environment. The hexavalent form is more toxic than the trivalent one [4].

Inhalation and retention of $\mathrm{Cr}(\mathrm{VI})$ containing material can cause damage to internal organs [5]. Skin contact of chromium (VI) compounds can lead to skin diseases [6]. The toxicological impact of chromium (VI) originates from its oxidizing ability as well as from the formation of free radicals during the reduction of $\mathrm{Cr}$ (VI) to $\mathrm{Cr}$ (III) occurring inside the cell [7].

Many physicochemical methods for heavy metal removal from aqueous solution have been developed. These methods include precipitation, resin chelation, electrochemical deposition, reverse osmosis, ion exchange, coagulation and solid-phase extraction [8]. These techniques however, have disadvantages such as incomplete metal removal, high reagent and energy requirements and generation of toxic sludge [9]. Cost effective alternative technologies to conventional methods are essential for the removal of heavy metals from industrial effluent. An innovative technique that is both efficient and economical is termed bioremediation or biosorption [10-12]. This has resulted in the easy and efficient removal of metals that could not be removed by other techniques. The major advantages of biosorption over other conventional treatment methods include low cost, high efficiency, minimization of chemical and biological sludge, and regeneration of biosorbent by desorption 
techniques and possibility of metal recovery [13]. In recent years, certain raw waste products from agricultural produce, like cocoa shell [14], rice husk, [15], olivestone [16], garlic peel [17], sawdust [18], Brazilian pine-fruit shell [19] banana peel [20], Carica papaya (pawpaw) seed [21], Anabaena and Vetiveria [22] and date tree leaves [23], have been tested for removal of metals from effluents. The utilization of these raw plant materials as biosorbents has been limited due to the leaching of organic compounds such as, cellulose lignin, pectin and lignocellulose into solution. Chemical modification on solid biomasses has been used as a remedy to improve their physical, chemical and biosorption capacity [24, 25].

The application of orange peel as a biosorbent material presents strong potential due to its main components of cellulose, pectin, hemicellulose and lignin which contain functional groups as possible binding sites for metals [26], [27]. Orange peel is an attractive and economic alternative for the removal of metal ions from waste water. The aim of this work was to study the adsorption capacity of orange peel that was chemically modified with sodium hydroxide for removing $\mathrm{Cr}$ (VI) ions from aqueous solutions. The effects of contact time, initial metal ion concentration, $\mathrm{pH}$ and biosorbent dosage on the biosorption efficiency were also investigated. The equilibrium data was tested on adsorption-type isotherms.

\subsection{Chemicals and instruments}

\section{Materials and methods}

All the chemicals used in this study were of analytical grade. $\mathrm{K}_{2} \mathrm{Cr}_{2} \mathrm{O}_{7}, \mathrm{HNO}_{3}$ and $\mathrm{NaOH}$ were supplied by Skylabs. Instruments used were Flame Atomic Absorption Spectrometer (FAAS) (Spectra AA 50B Varian), Fourier Transform Infra-red Spectrophotometer (FT-IR) (Digilab Merlin 2000 model Samitar) and Brunauer Emmett Teller (BET) (Micromeritis ASAP 2020).

\subsection{Preparation of biosorbents}

\subsubsection{Preparation of raw orange peel}

The biowaste material used for the study was obtained from a local market. The orange peels were washed with distilled water, dried in an oven at $80^{\circ} \mathrm{C}$ to constant mass and crushed into smaller particles of approximate size $\leq 200 \mu \mathrm{m}$. The resulting powder was washed with distilled water several times, oven dried at $80^{\circ} \mathrm{C}$ to constant mass and then put in air tight bottles and stored in a desiccator for further use in FT-IR analysis, batch experiments and chemical modification.

\subsubsection{Chemical modification of orange peel}

The crushed orange peel was treated with $\mathrm{NaOH}$ to improve the efficiency of metal uptake. In this study $100 \mathrm{~g}$ of dried orange peel biomass was treated with $1 \mathrm{~L}$ of $(0.1 \mathrm{M}) \mathrm{NaOH}$ for $48 \mathrm{~h}$ with shaking at 120 $\mathrm{rpm}$. After repeated decantation and filtration, the modified biomass was washed with distilled water until the $\mathrm{pH}$ value of solutions was neutral. The modified orange peel was then oven dried at $80^{\circ} \mathrm{C}$ to constant mass, put in air tight bottles and stored in a desiccator for further use in batch experiments and FT-IR analysis.

\subsection{Characterization of biosorbent}

FT-IR spectroscopy was used to identify the functional groups in the orange peel biosorbent. FT-IR spectra of the biosorbent before and after biosorption of $\mathrm{Cr}$ (VI) were recorded in the range $4000-400 \mathrm{~cm}^{-1}$ using a Digilab Merlin 2000 model FT-IR spectrometer with KBr discs (Sigma).

\subsection{Preparation of $\mathrm{Cr}$ (VI) stock solution}

Stock solution $(1000 \mathrm{mg} / \mathrm{L})$ of $\mathrm{Cr}(\mathrm{VI})$ was prepared by dissolving $\mathrm{K}_{2} \mathrm{Cr}_{2} \mathrm{O}_{7}$ in deionized water. For biosorption experiments, $\mathrm{Cr}$ (VI) solutions $(100 \mathrm{mg} / \mathrm{L})$ were prepared from the stock solution by dilution. Calibration standards 5, 10, 20,50 and $100 \mathrm{mg} / \mathrm{L}$ were prepared and used for calibrating the FAAS. The $\mathrm{pH}$ of the solution was adjusted using either $0.1 \mathrm{M} \mathrm{HNO}_{3}$ or $0.1 \mathrm{M} \mathrm{NaOH}$ solutions.

\subsection{Batch equilibrium studies}

$50 \mathrm{~mL}$ of $\mathrm{Cr}(\mathrm{VI})$ solution $(100 \mathrm{mg} / \mathrm{L})$ at the uncontrolled $\mathrm{pH}$ was taken in a $250 \mathrm{~mL}$ conical flask with a fixed dosage $(2 \mathrm{~g} / \mathrm{L})$ of sorbent. The mixture was agitated on a shaker at a speed of $120 \mathrm{rpm}$ at room temperature for a time which was sufficient for the chromium uptake process to reach equilibrium. Batch adsorption studies were performed at room temperature at different $\mathrm{pH}(1,2,3,4,6$, and 8), sorbent dose $(0.2$, $0.4,0.6,0.8,1.0,2.0,3.0,4,0$ and $5.0 \mathrm{~g})$, initial $\mathrm{Cr}(\mathrm{VI})$ concentration $(2,5,10,20,50$ and $100 \mathrm{mg} / \mathrm{L})$ and contact time ( $30 \mathrm{~min}, 1 \mathrm{~h}, 2 \mathrm{~h}, 3 \mathrm{~h}$ and $4 \mathrm{~h}$ ) to obtain the equilibrium data. All experiments were performed in replicates with reprocidubility within at most $5 \%$ error and the results average was reported.

After attainment of equilibrium, the samples were filtered through Whatman No. 1 filter paper and the residual $\mathrm{Cr}$ (VI) concentration in the filtrate was estimated using the FAAS. The amount of metal ion adsorbed per gram of biomass and the sorption efficiency (\%) were calculated according to the following expressions; 
$Q_{\theta}=\frac{\left(C_{o}+C_{\theta}\right) V}{M}$

Sorption efficiency $=\frac{\left(C_{o}-C_{o}\right)}{C_{o}} \times 100$

Where, $Q_{e}$ is the amount of $\mathrm{Cr}(\mathrm{VI})$ biosorbed per gram of biomass, $\mathrm{mg} / \mathrm{g}, C_{o}$ and $C_{e}$ are the initial and equilibrium concentrations of $\mathrm{Cr}(\mathrm{VI})(\mathrm{mg} / \mathrm{L})$ respectively, $V$ is the volume of solution $(\mathrm{L})$, and $M$ is the mass of biosorbent $(\mathrm{g})$.

The experimental data tested for conformity to Langmuir and Freundlich isotherm models from their linearized equations. The $\mathrm{R}^{2}$ (regression coefficient square value) and isotherm constants values were deduced from the models.

\subsection{Characterization of the biosorbent}

\section{Results and discussion}

\subsubsection{FT-IR analysis of biosorbent}

Infrared techniques have been used for identification of functional groups in biomaterials. In order to determine which functional groups were responsible for metal uptake, FT-IR spectra of the biosorbent before and after Cr (VI) bonding were recorded in the range of $4000-400 \mathrm{~cm}^{-1}$. The FT-IR spectrum of raw orange as shown in Fig. 1 exhibits a broad peak at $3420 \mathrm{~cm}^{-1}$, which is characteristic of the $\mathrm{O}-\mathrm{H}$ stretching vibrations of cellulose, pectin, hemicellulose, and lignin components. Free hydroxyl groups and bonded $\mathrm{OH}$ bands of carboxyl group were observed as the $\mathrm{OH}$ stretching vibrations occurred within a broad range of frequencies [28]. The band at $2920 \mathrm{~cm}^{-1}$ is attributed to C-H stretching vibration of methyl, methylene and methoxy groups. The peak observed at $1744 \mathrm{~cm}^{-1}$ is the stretching vibration due to non-ionic carboxyl groups (-COOH, $\mathrm{COOCH}_{3}$ ), and may be due to carboxylic acids or their esters. The peaks at 1760 and $1620 \mathrm{~cm}^{-1}$ may be due to asymmetric and symmetric stretching vibrations of the carbonyl groups in ionic carboxylic groups respectively. The peaks between 1400 and $1200 \mathrm{~cm}^{-1}$ may be as a result of symmetric stretching of - $\mathrm{COO}^{-}$of pectin. Peaks at $1060 \mathrm{~cm}^{-1}$ may be due to stretching vibration of $\mathrm{C}-\mathrm{OH}$ of alcohols and carboxylic acids [29].

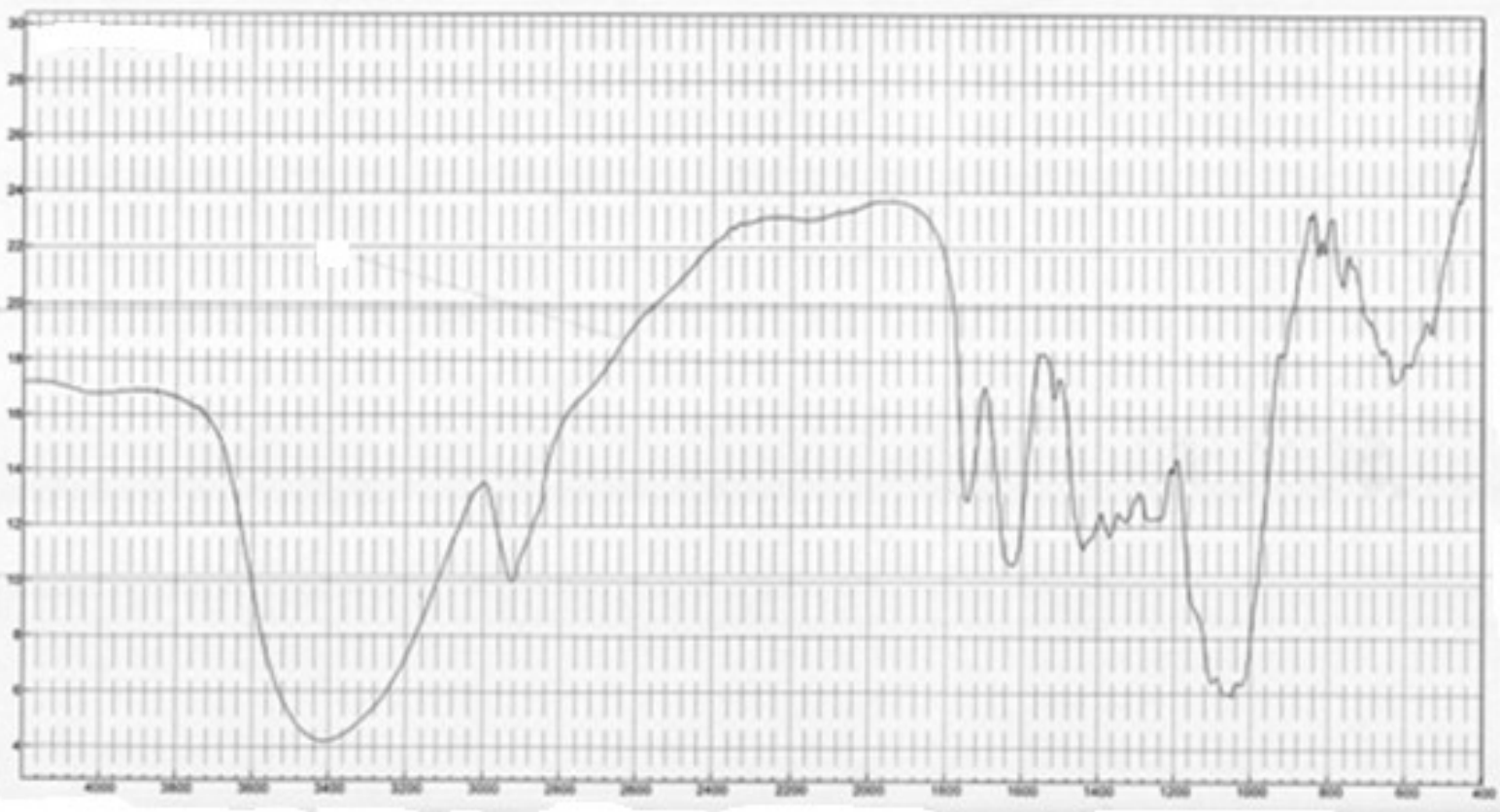

Fig 1. FT-IR spectrum of raw orange peel.

The FT-IR spectrum of orange peel modified with $\mathrm{NaOH}$ in Fig. 2 shows the weakening intensity of the peak at $1740 \mathrm{~cm}^{-1}$ indicating that the methyl esters were hydrolyzed with $\mathrm{NaOH}$ and the ester group was converted to the carboxylate ion [30]. 


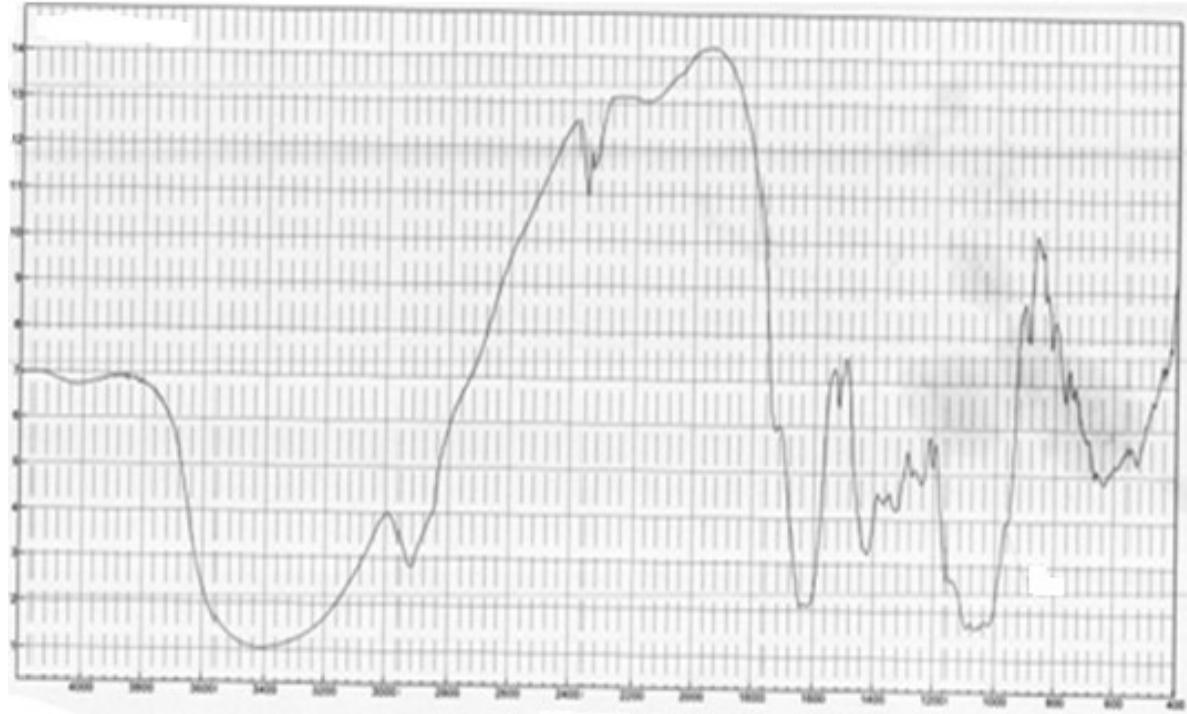

Fig. 2. FT-IR spectrum of chemically modified orange peel.

The FT-IR spectra after Cr (VI) sorption is shown in Fig. 3. Comparing the spectra before and after sorption of $\mathrm{Cr}(\mathrm{VI})$, differences in the position of the absorbance peaks appeared. The asymmetrical stretching vibration at $3420 \mathrm{~cm}^{-1}$ after the biosorption of $\mathrm{Cr}$ (VI) is significantly distorted suggesting that chemical interactions occur between the metal ions and the hydroxyl groups on the biosorbent surface. Notable changes in hydroxyl groups' peak were observed and thus further confirming their involvement in the sorption process. Slight shifting was observed on the asymmetric and symmetric $\mathrm{C}=\mathrm{O}$ band $\left(1760 \mathrm{~cm}^{-1}\right.$ to $1640 \mathrm{~cm}^{-1}$ and $1620 \mathrm{~cm}^{-1}$ to $1380 \mathrm{~cm}^{-1}$, respectively). The peak at $1060 \mathrm{~cm}^{-1}\left(\mathrm{C}-\mathrm{OH}\right.$ stretching of alcohols) disappeared while the peak at $1744 \mathrm{~cm}^{-1}$ shifted to $1640 \mathrm{~cm}^{-1}$ as the $\mathrm{OH}$ was involved in binding of $\mathrm{Cr}(\mathrm{VI})$. These results indicate that carboxyl and hydroxyl groups are involved in $\mathrm{Cr}(\mathrm{VI})$ bonding to the orange waste.

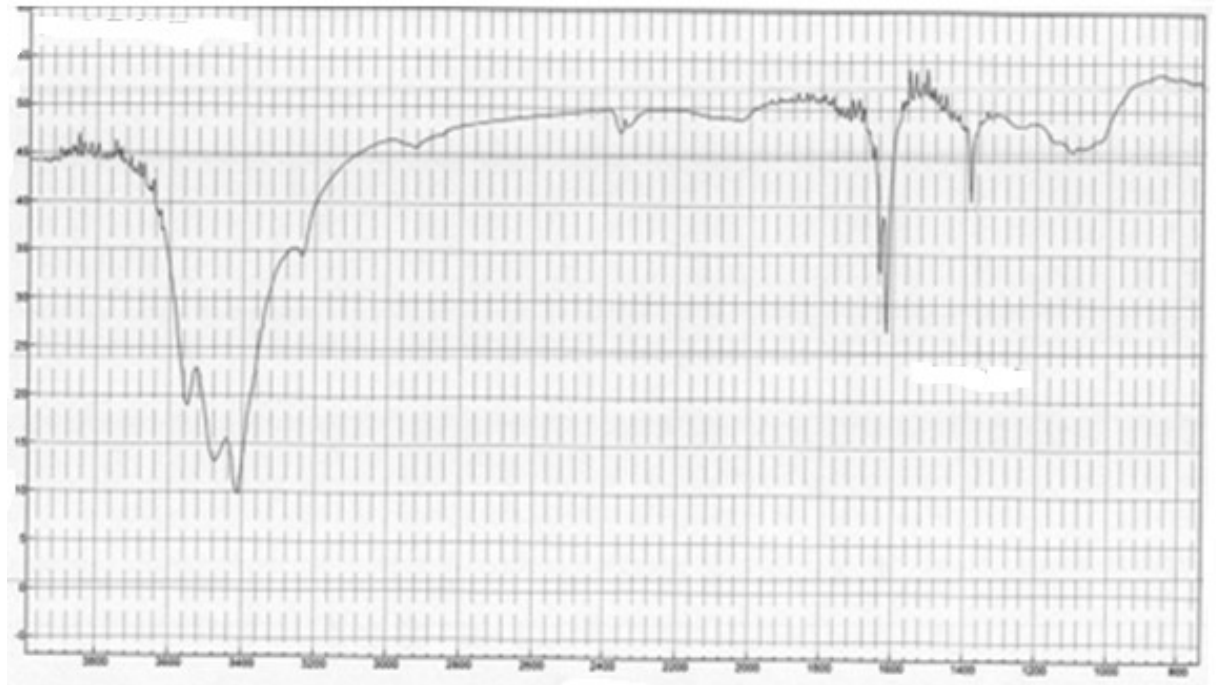

Fig. 3. FT-IR spectrum of raw orange peel after $\mathrm{Cr}(\mathrm{VI})$ sorption.

\subsubsection{Surface area analysis}

Table 1 gives a summary of some of the physical properties of the orange peel which were determined by BET. The $\mathrm{N}_{2}$ adsorption gave the specific surface area $\left(\mathrm{S}_{\mathrm{BET}}\right)$ of $0.8311 \mathrm{~m}^{2} / \mathrm{g}$ and the value is close to other values reported in literature for orange peels [30].

Table 1. Physical properties of orange peel

\begin{tabular}{ll}
\hline Property & Magnitude \\
\hline Surface area $\left(\mathrm{m}^{2} \mathrm{~g}^{-1}\right)$ & 0.8311 \\
Total pore volume $\left(\mathrm{cm}^{3} \mathrm{~g}^{-1}\right)$ & 0.000246 \\
Pore diameter $(\AA)$ & 23.699
\end{tabular}




\subsection{Batch biosorption experiments}

\subsubsection{Effect of pH on Cr (VI) uptake}

The $\mathrm{pH}$ of the solution affects the protonation of the functional groups on the biomass as well as the metal chemistry. Fig. 4 shows the removal of $\mathrm{Cr}(\mathrm{VI})$ at varying $\mathrm{pH}$ range applying an initial constant $\mathrm{Cr}$ (VI) concentration of $100 \mathrm{mg} / \mathrm{L}$, biosorbent concentration of $2 \mathrm{~g} / \mathrm{L}$ and contact time of $180 \mathrm{~min}$. As illustrated in Fig. 4, the maximum adsorption of $\mathrm{Cr}$ (VI) ions was observed at $\mathrm{pH} 2.0$ for both biosorbents and significantly decreased by increasing the $\mathrm{pH}$ values up to 8.0. This observation may be attributed to the fact that by decreasing $\mathrm{pH}$, hydroxyl groups in lignocellulosic wastes, tend to diffuse into the solution, so, it would be more probable for $\mathrm{Cr}_{2} \mathrm{O}_{7}^{2-}$ ions to be adsorbed on available adsorption sites. At lower $\mathrm{pH}$, the biosorbent is positively charged due to protonation resulting in electrostatic attraction with the dichromate [31]. A sharp decrease in adsorption above $\mathrm{pH} 2$ may be due to occupation of the adsorption sites by anionic species like $\mathrm{HCrO}_{4}{ }^{-}, \mathrm{Cr}_{2} \mathrm{O}_{7}{ }^{2-}$ or $\mathrm{CrO}_{4}{ }^{2-}$ which retards the approach of such ions further toward the sorbent surface [32, 33].

Uptake of $\mathrm{Cr}(\mathrm{VI})$ increased markedly with decreasing $\mathrm{pH}$. At $\mathrm{pH} 2$ and 8 corresponding uptake yield values were found to be $37.2 \%$ and $17.4 \%$ for raw orange peel, $38.6 \%$ and $18.6 \%$ for chemically modified orange peel respectively. The decrease in adsorption at high $\mathrm{pH}$ values may be due to the competitiveness of the oxyanion of chromium and $\mathrm{OH}^{-}$ions in the bulk. These results suggest that $\mathrm{pH}$ affects the solubility of metals and the ionization state of the functional groups like carboxylate, phosphate and amino groups of the cell walls of the biosorbent [34-37].

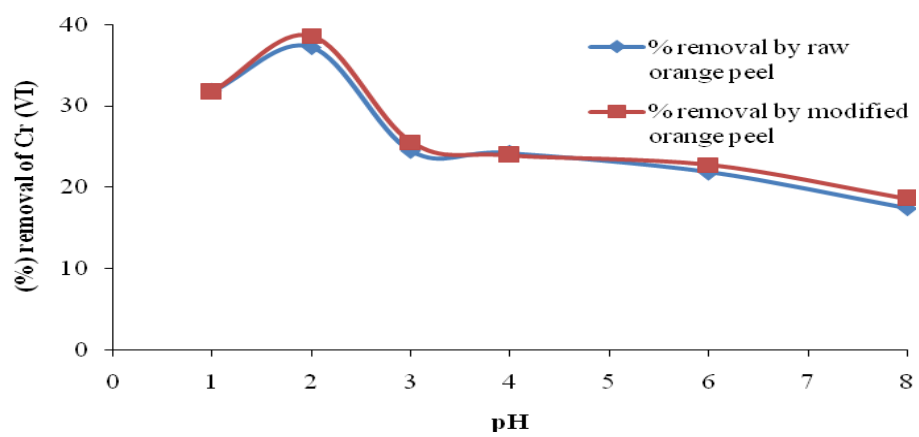

Fig. 4. Effect of $\mathrm{pH}$ on the biosorption of $\mathrm{Cr}(\mathrm{VI})$

\subsubsection{Effect of contact time on $\mathrm{Cr}$ (VI) uptake}

The time required for the biosorption of $\mathrm{Cr}(\mathrm{VI})$ on $2 \mathrm{~g} / \mathrm{L}$ raw and chemically modified orange peels to equilibrate was studied. Fig. 5 illustrates the effect of contact time on adsorption efficiency of $\mathrm{Cr}$ (VI). The initial concentration was kept constant at $100 \mathrm{mg} / \mathrm{L}$ and $\mathrm{pH}$ was set at 2.0 . The experimental data indicate that $\mathrm{Cr}$ (VI) ion adsorption increased with increasing contact time. This is due to prolonged contact between the sorbent surface and the chromium ion. Fig. 5 shows that adsorption capacity sharply increased with increase in time and attains equilibrium in $180 \mathrm{~min}$ for both adsorbents $(29.8 \%$ for modified orange peel and $29.6 \%$ percentage uptake for raw orange peel respectively). The rate of adsorption is higher within the first 20 min due to large available surface area of the biosorbent and a high concentration gradient. After the active sites of the adsorbent gets exhausted, when equilibrium is attained, the rate of uptake is controlled by the rate at which the adsorbate is transported from the exterior to the interior sites of the biosorbent particles [38].

Lower adsorption rate in the latter stage (after $180 \mathrm{~min}$ ) was due to the difficulty encountered by $\mathrm{Cr}$ ions in occupying the remaining vacant surface sites because of forces between the solute molecules of the solid and bulk phase [39]. This may also be due to intraparticle diffusion process dominating over adsorption [40]. The results also indicate that chemically modified orange peel showed better sorption capacities than the raw orange peel.

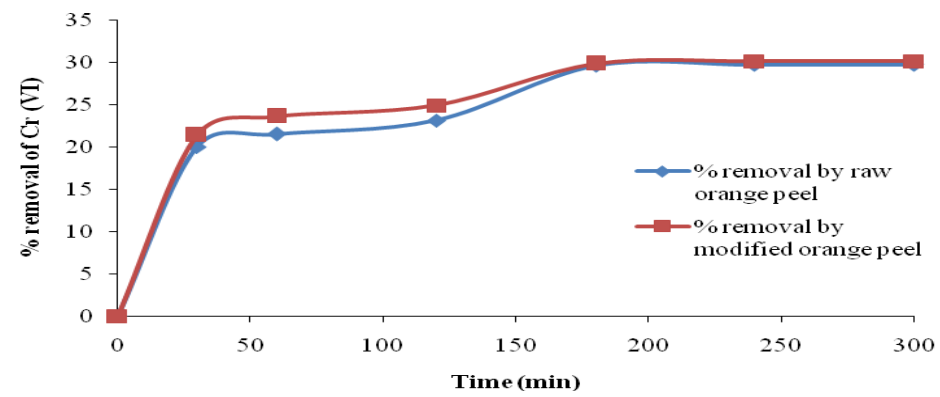

Fig. 5. Effect of contact time on the biosorption of $\mathrm{Cr}(\mathrm{VI})$. 


\subsubsection{Effect of biosorbent dosage on Cr (VI) uptake}

The effect of biosorbent dosage on the removal of chromium (VI) at room temperature was investigated by varying the amount of sorbent from 0.2 to $5 \mathrm{~g} / \mathrm{L}$ and agitated at $120 \mathrm{rpm}$ for $180 \mathrm{~min}$ using initial $\mathrm{Cr}(\mathrm{VI})$ ion concentration of $100 \mathrm{mg} / \mathrm{L}$ and at $\mathrm{pH}$ value of 2.0. The results indicate that the percent removal of chromium (VI) increased with the increase in the amount of adsorbent and the removal efficiency for chemically modified orange peel was better than that of the raw orange peel as illustrated in Fig. 6.

The highest uptake was obtained at biosorbent concentration of $4 \mathrm{~g} / \mathrm{L}$ for both biosorbents at $41.4 \%$ and $39.9 \%$ uptake for modified and raw orange peels respectively. The removal of metal ions increased with the increase in biosorbent concentration and equilibrium was attained after $4 \mathrm{~g} / \mathrm{L}$ of adsorbent dosage for the chromium (VI) ions. This is due to availability of more biosorbent sites as well as enhanced surface area [41]. The decrease in the rate of $\mathrm{Cr}(\mathrm{VI})$ uptake at adsorbent dose greater that $2 \mathrm{mg} / \mathrm{L}$ may be due to competition of the $\mathrm{Cr}$ (VI) ion for the sites available [42]. Similar results are also reported by researchers for a variety of batch experiments on sorption $[29,36,43-45]$.

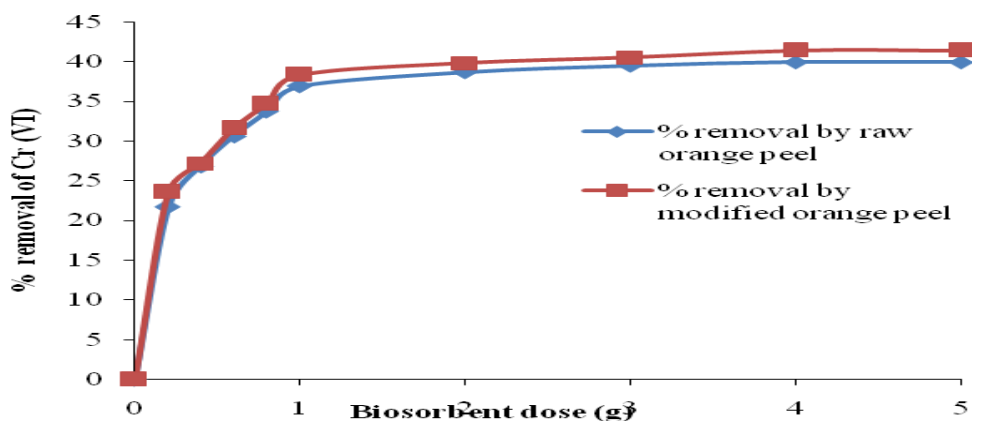

Fig. 6. Effect of biosorbent dosage on the biosorption of $\mathrm{Cr}(\mathrm{VI})$.

\subsubsection{Effect of initial metal concentration on Cr (VI) uptake}

Effect of initial $\mathrm{Cr}(\mathrm{VI})$ ion concentration on its removal was carried out at optimized adsorbent dose $(4 \mathrm{~g} / \mathrm{L})$, contact time $(180 \mathrm{~min})$ and $\mathrm{pH}(2.0)$ at room temperature by varying the metal ion concentration from 2$100 \mathrm{mg} / \mathrm{L}$. At lower $\mathrm{Cr}$ (VI) concentrations, the ratio of the initial number of moles of metal ions to the available surface area is smaller and subsequently the fractional adsorption process becomes independent of the initial concentrations. However, at higher concentrations, the available sites of adsorption become fewer, and hence the percentage removal of metal ions depends upon the initial concentration. The percentage of $\mathrm{Cr}$ (VI) ions uptake for both biosorbents increased with the initial metal concentrations as expected and remained nearly constant after equilibrium time as shown in Fig. 7. It also showed that the adsorption was rapid in the initial stages upto $50 \mathrm{mg} / \mathrm{L}$ and gradually decreased with progress of adsorption. Similar results were obtained by [46]. This can be attributed to the saturation of sorption sites on adsorbents. The initial concentration provides a significant driving force to overcome all mass transfer resistance of metals ion between aqueous and solid phases. Hence, a higher initial concentration of $\mathrm{Cr}(\mathrm{VI})$ increased the rate of biosorption [33].

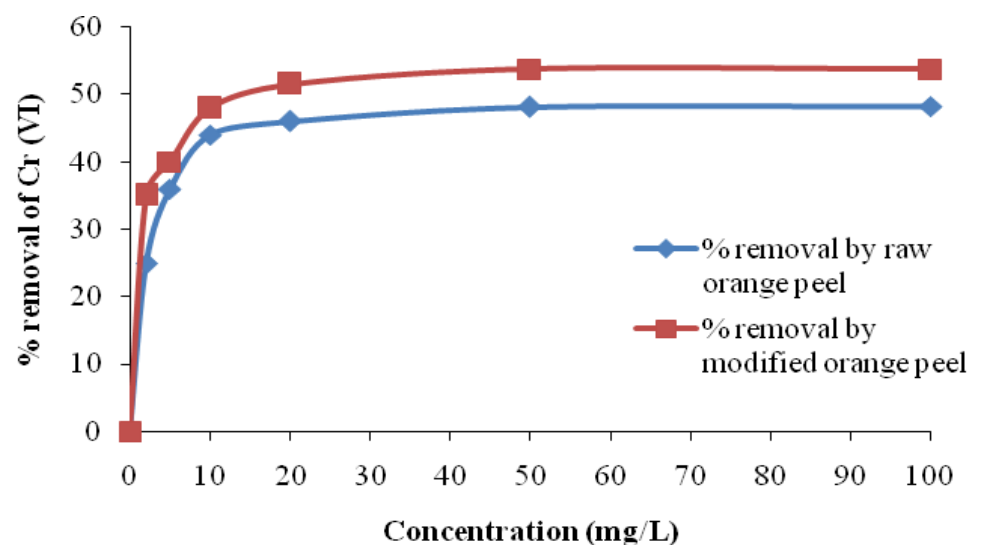

Fig. 7. Effect of initial metal concentration on the biosorption of $\mathrm{Cr}$ (VI). 


\subsection{Adsorption isotherms}

The equilibrium biosorption of $\mathrm{Cr}$ (IV) ions was modeled using the adsorption-type isotherm. The Freundlich isotherm model produce a better fit than the Langmiur one and is therefore used to describe the biosorption equilibrium of the biomass. The Freundlich model proposes a monolayer sorption with a heterogeneous energetic distribution of active sites accompanied by interactions between adsorbed molecules. This can be linearized as;

$\log Q_{\theta}=\log K_{f}+\frac{1}{n} \log C_{\theta}$

Where $\mathrm{Q}_{\mathrm{e}}$ is the amount of chromium (VI) adsorbed by orange peel biomass $(\mathrm{mg} / \mathrm{g}) \mathrm{C}_{\mathrm{e}}$ is equilibrium adsorbate concentration in $\mathrm{mg} / \mathrm{L}, \mathrm{K}_{\mathrm{f}}$ is the adsorbent capacity measure and $\mathrm{n}$ is the adsorption intensity.

Fig. 8 shows the Freundlich isotherm model of $\mathrm{Cr}$ (VI). In the Freundlich model a linear plot of $\log \mathrm{Q}_{\mathrm{e}} \mathrm{vs} \log \mathrm{C}_{\mathrm{e}}$ give a straight line for both biosorbents with $\mathrm{R}^{2}=0.987$ and 0.995 for the raw and the chemically modified orange peels respectively. The $\mathrm{R}^{2}$ values of the Freundlich model is greater than 0.95 , indicating applicability of this model. The equilibrium data agreed well with the Freundlich isotherm than the Langmuir one and thus for this study only the former was reported. The values for $\mathrm{K}_{\mathrm{f}}$ and $\mathrm{n}$ were found to be $(97.07 ; 0.79)$ and $(139 ; 0.82)$ for the raw and modified orange peels respectively. The adsorption capacity $\left(\mathrm{K}_{\mathrm{f}}\right)$ of $\mathrm{Cr}(\mathrm{VI})$ on modified orange peel is $139 \mathrm{mg} / \mathrm{g}$ which is higher than that of raw orange peel $\left(\mathrm{K}_{\mathrm{f}}=97.07\right)$ thus indicating the efficiency of the sodium hydroxide modification process.

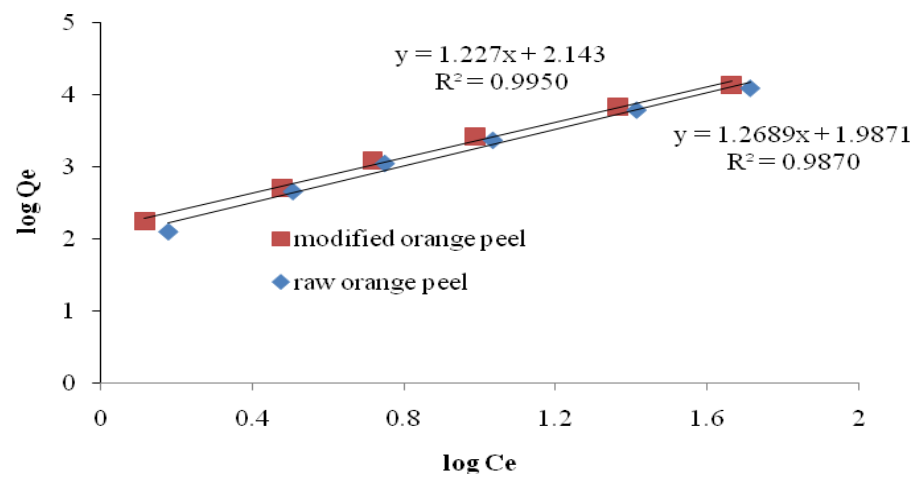

Fig. 8. Freundlich isotherm model for biosorption of $\mathrm{Cr}(\mathrm{VI})$.

A comparison of Freundlich parameters for the biosorption of $\mathrm{Cr}(\mathrm{VI})$ in the present research and in other studies where different biosorbents were used are shown in Table 2. It can be seen that the $\mathrm{K}_{\mathrm{f}}$ and $\mathrm{R}^{2}$ values for the current study are higher than those obtained in past studies (Table 2) and thus it is observed that modified orange peel is a better biosorbent for the removal of $\mathrm{Cr}(\mathrm{VI})$ ions from aqueous solution.

Table 2. Overview summary of Freundlich isotherm parameters on selected studies on $\mathrm{Cr}$ (VI) sorption by biosorbents.

\begin{tabular}{|c|c|c|c|c|}
\hline Biosorbent & $\overline{\mathbf{R}^{2}}$ & n $(\mathrm{g} / \mathrm{L})$ & $\begin{array}{c}\mathbf{K}_{\mathbf{f}} \\
{[\mathrm{mg} / \mathrm{g}} \\
\left.(\mathrm{L} / \mathrm{mg})^{\mathrm{n}}\right]\end{array}$ & Reference \\
\hline Raw wheat husk & 0.9171 & 2.237 & 4.5708 & [41] \\
\hline Raw maize bran & 0.8910 & 4.470 & 0.313 & [44] \\
\hline $\begin{array}{l}\text { Raw sugarcane } \\
\text { bagasse }\end{array}$ & 0.8909 & 2.08 & 2.9471 & [41] \\
\hline Raw pine needles & 0.9843 & 3.74 & 21.22 & [43] \\
\hline Raw coconut husk & 0.9627 & 0.788 & 0.02468 & [44] \\
\hline $\begin{array}{l}\text { Oxalic acid treated } \\
\text { tamarind fruit shell }\end{array}$ & 0.9800 & 0.800 & 4.8700 & [28] \\
\hline $\begin{array}{l}\mathrm{NaOH}-\text { modified } \\
\text { coconut husk }\end{array}$ & 0.9595 & 1.088 & 0.10864 & [44] \\
\hline Raw orange peel & 0.9870 & 0.79 & 97.07 & $\begin{array}{l}\text { (Present } \\
\text { study) }\end{array}$ \\
\hline $\begin{array}{l}\mathrm{NaOH} \text {-modified } \\
\text { orange peel }\end{array}$ & 0.9950 & 0.82 & 139.0 & $\begin{array}{l}\text { (Present } \\
\text { study) }\end{array}$ \\
\hline
\end{tabular}

\section{Conclusion}

The modification of orange peel with sodium hydroxide enhances the removal efficiency of $\mathrm{Cr}$ (VI) ions from aqueous solutions. Characterization of the biomass suggested the possible contribution of carboxyl and hydroxyl groups of the biomass in $\mathrm{Cr}$ (VI) biosorption. The removal of $\mathrm{Cr}$ (VI) from aqueous solutions is 
strongly depended on $\mathrm{pH}$ of the solution, adsorbent dosage, initial $\mathrm{Cr}(\mathrm{VI})$ concentration, and contact time. The maximum adsorption of $\mathrm{Cr}(\mathrm{VI})$ was obtained at $\mathrm{pH} 2.0$, adsorbent dosage of $4.0 \mathrm{mg} / \mathrm{L}$ and a contact time of 180 min. The biosorption equilibrium data fitted well to the Freundlich isotherm. The adsorption capacities $\left(\mathrm{K}_{\mathrm{f}}\right)$ were 97.07 and $139.0 \mathrm{mg} / \mathrm{g}$ for raw and chemically modified orange peels respectively. Orange peel is an easily available material from citrus processing industries and can therefore be applied for the removal of $\mathrm{Cr}$ (VI) in industrial effluent before it is discharged into water bodies.

\section{Acknowledgement}

This work was supported financially by Midlands State University, Zimbabwe. We would like to thank Varichem Pharmaceutical Company, Zimbabwe for Fourier Transform-Infrared analysis (FT-IR) analysis, Tshwane University of Technology, Department of Chemistry, South Africa for the use of the BET and Zimalloys (Pvt) Ltd, Zimbabwe for Flame Atomic absorption spectroscopy (FAAS) analysis.

\section{References}

[1] Marín, A.B.P., Aguilar, M.I., Meseguer, V.F., Ortuńo, J.F., Sáez, J. and Lloréns, M. "Biosorption of chromium (III) by orange (Citrus Cinesis) waste: batch and continuous studies. Chemical Engineering Journal”, vol 155, pp.199-206, 2009.

[2] Sud, D., Mahajan, G. and Kaur, N.P. "Agricultural waste material as potential adsorbent for sequestering heavy metal ions form aqueous solutions: A review”. Bioresource Technology, vol. 99, pp. 6017-6027, 2008.

[3] Wu, D., Sui, Y, He, S., Wang, X., Li, C. and Kong, H. "Removal of trivalaent chromium from aqueous solution by zeolite synthesized from coal fly ash.” Journal of Hazardous Materials, vol. 155, pp. 415-423, 2008.

[4] Kowalski, Z. "Treatment of chromic tannery wastes". Journal of Hazardous Materials, vol. 37, pp.137-144, 1994.

[5] Hussein, L., Warner, H. and Elke, G. "Fate of heavy metal in the leather tanning industrial". Environmental Management and Health, vol. 6, pp. 28-33, 1995

[6] Juang, R.S. and Shiau, R.C. "Metal removal from aqueous solutions using chitosan-enhanced membrane filtration". Journal of Membrane Science, vol. 165, pp. 159-167, 2000

[7] Egli, H., Dassenakis, M., Garelick, H., Van Grieken, R., Peijnenburg, W., Klasinc, L., Kördel, W., Priest, N. and Tavares, T.. "Minimum requirements for reporting analytical data for environmental samples". Pure and applied Chemistry, vol. 75, pp. 10971106,2003

[8] Petrik, L. "Environmental impact of the placing of coal residue, fine coal residue and ash in mined out areas". Journal of Environmental Science, vol. 43, pp.132-145, 2004.

[9] Ong, S., Lim, P., Seng, C., Hirata, M and Hano, T. "Effect of Cu (II) and Cd (II) performance of sequencing batch reactor treatment system". Journal of Process Biochemistry, vol. 40, pp. 453-460, 2004

Ambe, S., Ambe, F. and Nozaki, T. "Tracer and Mossbauer Studies of iron and cobalt in water hyacinth roots". International Journal of Applied Radiation and Isotopes, vol. 36, pp. 7-11, 1985.

[11] Mudhoo, A., Garg, V.K. and Wang, S. "Heavy metals: Toxicity and removal by biosorption". Environmental Chemistry for a Sustainable World, vol. 2. pp. 379-442, 2012.

Perpetuo, E.A., Souza, C.B. and Nascimento, C.A.O. "Engineering bacteria for bioremediation". Progress in Molecular and Environmental Bioengineering-From Analysis and Modeling to Technology Applications, vol. 28. pp. 605-632, 2011.

[13] Yan, G. and Viraraghavan T. "Heavy metal removal in a biosorption column by immobilized M. Rouxii biomass". Bioresoure Technology, vol. 78, pp. 243-249, 2001.

[14] Thievarasu, C., Mylsamy, S. and Sivakumar, N. "Cocoa shell as adsorbent for the removal of methylene blue from aqueous solution: Kinetic and Equilibrium study". Universal Journal of Environmental Research and Technology, vol 1, pp. 70-78, 2011.

[15] Bishnoi, N.R., Bajaj, M., Sharma, N. and Gupta, A. "Adsorption of Cr (VI) on activated rice husk carbon and activated alumina". Bioresource Technology, vol. 91, pp. 305-307, 2004

[16] Fiol, N., Villaescusa, I., Martinez, M., Miralles, N., Poch, J. and Serarols, J. "Sorption of Pb (II), Ni (II), Cu (II) and Cd (II) from aqueous solution by olive stone waste". Separation and Purification Technology, vol. 150, pp.132-140, 2006.

[17] Hameed, B.H and Ahmad, A.A. "Batch adsorption of methylene blue from aqueous solution by garlic peel, an agricultural waste biomass". Journal of Hazardous Materials, vol. 164, pp. 870-875, 2009.

[18] Garg, B. and Acemioglu, B. "Adsorption of Congo red from aqueous solution onto activated sawdust", Journal of Colloid Interfacial Science, vol. 25, pp. 371-379, 2003

[19] Lima, M., Pius, A. and Zhu, Z. H. "Removal of dyes from aqueous solution using modified groundnut husks". Journal of Waste Resource Management, vol. 39, pp.129-138, 2008.

[20] Achak, M., Hafidi, A., Ouazzani, N., Sayadi, S. and Mandi, L. "Low cost biosorbent banana peel for the removal of phenolic compounds from olive mill waste water: kinetic and equilibrium studies". Journal of Hazardous Materials, vol. 166, pp. 117-125, 2009.

[21] Egila, J.N., Dauda, B.E.N., Iyaka, Y.A. and Jimoh, T. "Agricultural waste as a low cost adsorbent for heavy metal removal from wasteland". International Journal of the Physical Sciences, vol. 6, pp. 2152-2157, 2011.

[22] Pal, A. and Chaudhury, A.S. "Biosorption of chromium using Anabaena and Vetiveria". International Journal of Pollution Abatement Technology, vol. 1, pp. 15-19, 2012

[23] Boudrahem, F., Aissani-Benissad, F. and Soulah, A. "Adsorption of Lead (II) from aqueous using leaves of date trees as an adsorbent". Journal of Chemical. Engineering Data, vol. 56, pp. 1804-1812, 2011.

[24] Yeneneh, A.M., Maitra, S. and Eldermerdash, U. "Study of biosorption of heavy metals by modified lignocellulosic waste". Journal of Applied Sciences, vol. 11, pp. 3555-3562, 2011

[25] Anirudhan, T.S., Noeline, B.F. and Manohar, D.M. "Phosphate removal from wastewaters using a weak anion exchanger prepared from a lignnocellulosic residue”. Environmental Science Technology, vol. 40, pp. 2740-2745, 2006.

[26] Kaushik, C.P., Tuteja, R., Kaushik, N. and Sharma, J.K. "Minimization of organic chemical load in direct dyes effluent using low cost adsorbents". Chemical Engineering Journal, vol. 155, pp. 234-240, 2009.

[27] Gaballah, I., Goy, D., Allain, E., Kilbertus, G. and Thauront, J. "Recovery of copper through decontamination of synthetic solutions using modified bark". Metallurgical and Materials Transactions B, vol. 28, pp. 13-23, 1997. 
[28] Marín, A.B.P., Aguilar, M.I., Meseguer, V.F., Ortuńo, J.F., Sáez, J. and Lloréns, M. "Biosorption of Zn (II) by orange waste in batch and packed-bed systems". Journal of Chemical Technology and Biotechnology", vol. 85, pp. 1310-1318, 2010.

[29] Liang, S., Guo X, Feng N. and Tian, Q. "Adsorption of $\mathrm{Cu}^{2+}$ and $\mathrm{Cd}^{2+}$ from aqueous solution by mercapto-acetic acid modified orange peel". Journal of Colloids Surfaces and Biointerfaces, vol. 73, pp. 10-14, 2009.

[30] Feng, N. Guo, X., Liang, S., Zhu, Y. and Liu, J. "Biosorption of heavy metals from aqueous solutions by chemically modified orange peel”. Journal of Hazardous Materials, vol. 185, pp. 49-54, 2009.

[31] Boddu, V.M., Abburi, K., Talbott, J.L. and Smith, E.D. "Removal of hexavalent chromium from wastewater using a new composite chitosan biosorbent". Journal of Environmental Science and Technology, vol. 37, pp. 4449-4456, 2003.

[32] Das, D.D., Mahapatra, R., Pradhan, J., Das, S.N. and Thakur, R.S. "Removal of Cr (VI) from aqueous solution using activated cow dung carbon". Journal of Colloid and Interface Science, vol. 232, pp. 235-240, 2000.

[33] Donmez, D. and Aksu, Z. "Removal of chromium (VI) from saline wastewaters by dunaliella species". Process Biochemistry, vol. 38, pp. 751-762, 2002.

[34] Popuri, S.R., Jammala A., Reddy, K.V.N.S. and Abburi, K. "Biosorption of hexavalent chromium using tamarind (Tamarindus indica) fruit shell: a comparative study". Electronic Journal of Biotechnology, vol.10, pp. 358-367, 2007.

[35] Pehlivan, E. and Altun, T. "Biosorption of chromium (VI) ion from aqueous solutions using walnut, hazelnut and almond shell". Journal of Hazardous Materials, vol. 155, pp. 378-384, 2008.

[36] Moussavi, G. and Barikbin, B. "Biosorption of chromium (VI) from industrial wastewater onto pistachio hull waste biomass". Chemical Engineering Journal, vol.162, pp. 893-900, 2010.

[37] Ahmadpour, A., Zabihi, M., Tahmasbi, M. and Bastami T.R. "Effect of adsorbents and chemical treatments on the removal of strontium from aqueous solutions”. Journal of Hazardous Materials, vol.182, pp. 552-556, 2010.

[38] Verma, A., Chakraborty, S. and Basu, J.K. "Adsorption study of hexavalent chromium using tamarind hull-based adsorbents". Separation and Purification Technology, vol. 50, pp. 336-341, 2006.

[39] Ucun, H., Bayhan, Y. K., Kaya, Y., Cakici, A and Algur, O. F. "Biosorption of chromium (Vl) from aqueous solutions by cone biomass of Pituis sylvestris". Bioresource Technology, vol. 85, pp. 155-158, 2002.

[40] Volesky, B. "Sorption and biosorption". BV-Sorbex Inc., St. Lambert, Quebec, Canada, 2003.

[41] Aoyama, M. "Removal of Cr (VI) from aqueous solution by London plane leaves". Journal of Chemical Technology and Biotechnology, vol. 78, pp. 601-604, 2003.

[42] Baral, S.S., Das, S.N. and Rath, P. "Hexavalent chromium removal from aqueous solution by adsorption on treated sawdust". Journal of Biochemical Engineering, vol. 31, pp. 216-222, 2006.

[43] Demirbas, M., Kobya, M. and Konukman, A.E.S. "Error analysis of equilibrium studies for the almond shell activated carbon adsorption $\mathrm{f} \mathrm{Cr}$ (VI) from aqueous solutions". Journal of Hazardous Materials, vol. 154, pp. 787-794, 2008.

[44] Ahmadpour, A., Tahmasbi, M., Bastami, T.R and Besharati, J.A. "Rapid removal of cobalt ion from aqueous solutions by almond green hull". Journal of Hazardous Materials, vol.166, 925-930, 2009.

[45] Tunali, S., Kiran, I. and Akar, T. "Chromium (VI) biosorption characteristics of Neurospora crassa fungal biomass". Mining and Engineering, vol. 18, pp. 681-689, 2005.

[46] Namasivayam C. and Suresh Kumar, M.V. "Removal of chromium (VI) from water and wastewater using surfactant modified coconut coir pith as a biosorbent". Bioresources Technology. Vol. 99, pp. 2218-2225, 2008.

[47] Vinodhini, V. and Das, N. "Biowaste materials as sorbents to remove chromium (VI) from aqueous environment: a comparative study". Journal of Agricultural and Biological Science, 4,19-23,2009.

[48] Hasan, S.H., Singh, K.K., Prakash, O., Talat, M and Ho, Y, S. "Removal of Cr (VI) from aqueous solution using agricultural waste maize bran". Journal of Harzadous Materials. 152, 356-365, 2008.

[49] Hadjmohammadi, M.R., Salary, M. and Biparva, P. "Removal of Cr (VI) from aqueous solution using pine needles powder as biosorbent". Journal of Applied sciences in Environmental Sanitation, vol 6: pp. 1-13, 2011.

[50] Olayinka, O, K., Oedeji, O, A. and Oyeyiola, O, A. "Removal of chromium and nickel ions from aqueous solution by adsorption on modified coconut husk". African Journal of Environmental Science and Technology, vol. 3, pp. 286-293, 2009.

\section{Authors' profile}

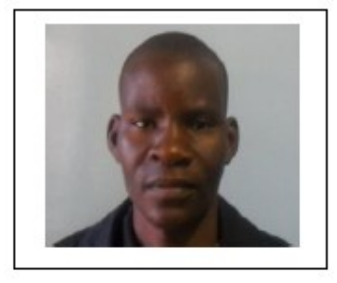

Mr Fidelis Chigondo obtained his BSc Honours degree in Chemistry from Midlands State University, Gweru, Zimbabwe in 2004. He acquired a Master of Technologiae degree (M-Tech Chemistry) in 2010 from Tshwane University of Technology, Pretoria, South Africa. He is currently lecturing at Midlands State University, Gweru, Zimbabwe in the Department of Chemical Technology. His area of expertise includes organic synthesis and methods of removal of contaminants from aqueous solutions using biosorbents.

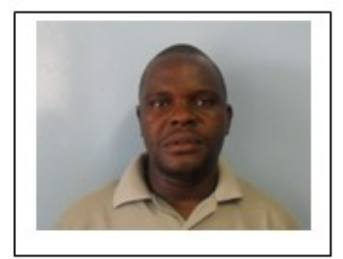

Mr Shadreck Mandina received his Dilpoma in Education in 1997 form Gweru Teacher's College, Zimbabwe. He then qualified with a BSc Honours degree in Chemistry from Midlands State University, Gweru, Zimbabwe in 2004. He obtained an Med in curriculum Studies in 2007. He attained an MSc degree in Material Chemistry from Midlands State University, Gweru, Zimbabwe in 2012. He is currently a lecturer in the Department of Educational Foundations, Management and Curriculum Studies, Midlands State University, Gweru, Zimbabwe. His research interests are in material science and biosorption. 

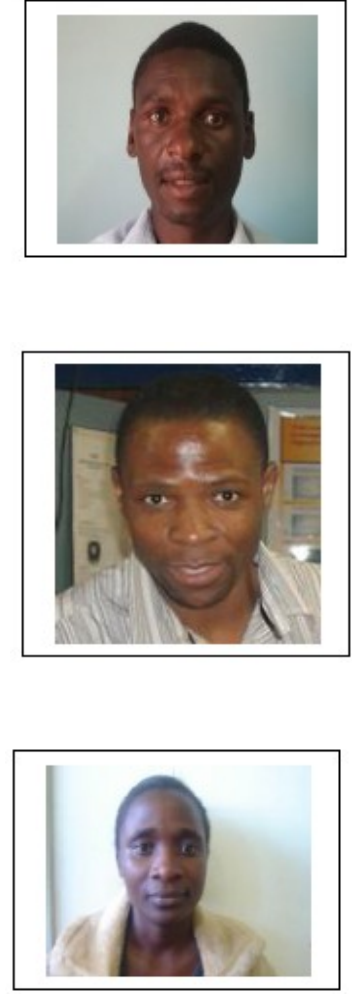

Mr Munyaradzi Shumba obtained his Diploma in Education from University of Zimbabwe in 1998. He obtained a BSc degree in Chemistry from the Bindura University of Science Education, Zimbabwe, 2005. He received his MSc degree in Inorganic Chemistry from Bindura University of Science Education, Zimbabwe in 2008. He is currently a lecturer and acting chairperson in the Department of Chemistry, Midlands State University, Gweru, Zimbabwe. His area of expertise includes co-ordination compounds, heavy metal speciation and chemistry education.

Mr Benias. C. Nyamunda received his BSc degree in Chemistry and Biochemistry, from University of Zimbabwe in 1995. He obtained his MSc degree in Analytical Chemistry from the University of Zimbabwe in 2007 and Certificate in Quality Assurance, City and Guilds, London (2001). He has submitted to assessors his PhD thesis for a degree in Chemistry from Department of Chemistry, Tshwane University of Technology, Pretoria, South Africa. He is also currently a part-time lecturer in the Department of Chemistry. His area of expertise includes catalysis and biosorption.

Miss Edith Sebata received her BSc Honours degree in Chemistry from Midlands State University, Gweru, Zimbabwe, 2004. She obtained her MSc degree in Chemistry from University of Kwazulu Natal, Durban, South Africa, 2009. She is currently a lecturer at Midlands State University, Gweru in the department of Chemistry. She specializes in researches that involve natural products and biosorption. 